\title{
Geographical characteristics of contemporary international migration in and into Europe
}

\author{
KÁRoly KOCSIS ${ }^{1}$, JUdit MOLNÁR SANSUM², LEA KREININ², GÁBOR MICHALKÓ", \\ Zsolt BOTTLIK ${ }^{3}$, Balázs SZABÓ${ }^{1}$, DÁNIEL BALIZS¹ and GYörgy VARGA ${ }^{1}$
}

\begin{abstract}
The study offers a short geographical overview of migration studies and theories, doing so in the context of the European migration crisis of 2015-2016. It outlines the history of international migrations affecting Europe (immigration, emigration, migration within Europe and between countries) and the demographic effects of such migration on the present European population. It then analyses and examines the global and regional causes of recent migration to Europe (the European Economic Area, EEA), the countries of origin of the migrants, the main routes of migration, and the destination areas in Europe. As far as intercontinental migration is concerned, Europe was characterised by emigration between the $16^{\text {th }}$ and mid-20 $0^{\text {th }}$ centuries (partly in consequence of colonisation) and mainly by immigration thereafter. Immigration has principally affected Western Europe, the more developed part of the continent. In consequence of post-World War II reconstruction, dynamic economic development, local labour shortages, and the decolonisation process, Western Europe received many migrants, initially from the Mediterranean region and subsequently (i.e. after the collapse of communism in 1989-1990) from the post-communist European countries. Meanwhile, the core areas of the EEA became the main destination for migrants coming from predominantly Muslim regions in Asia and Africa (SW Asia, Muslim Africa). This decades-old process has recently accelerated and now constitutes mass migration. The global and regional causes of such intercontinental migration in the sending areas are as follows: the population boom, economic backwardness, unemployment, growing poverty, climate change, desertification, negative ecological changes, global political rivalries and local power changes (e.g. the Arab Spring, 2011), growing political instability, wartime destruction, multiple and cumulative crises, general hopelessness and despair.
\end{abstract}

Keywords: migration, theories of migration, foreign-born population, allochtonous minorities, asylum seekers, refugees, Europe, Middle East, Africa

\section{Introduction}

Migration is a process which has existed since ancient times. It affects every dimension of social existence, and develops its own complex dynamics. According to UN DESA reports, in 2015 the number of international migrants worldwide was 243.7 million (3.3\% of the world population $)^{4}$ and the global population of international migrants is growing at about 1.6 percent anually. From 2000 to 2015, high-income countries received an average of 4.1 million net migrants each year from lower- and middle-income countries. The 2016 UNHCR Global Trends report finds 65.3 million people (or one person in 113) were displaced from their homes by conflict and persecution in 2015; they are now asylum seekers, internally displaced or refugees ${ }^{5}$. The great majority of people

\footnotetext{
${ }^{1}$ Geographical Institute, Research Centre for Astronomy and Earth Sciences, Hungarian Academy of Sciences, H-1112 Budapest, Budaörsi út 45. E-mails: kocsis.karoly@csfk.mta.hu, michalko.gabor@csfk.mta.hu, szabo.balazs@csfk.mta.hu, balizs.daniel@csfk.mta.hu, varga.gyorgy@csfk.mta.hu

${ }^{2}$ Central and East European Studies, University of Glasgow, 8-9 Lilybank Gardens, Glasgow G12 8RZ

E-mails: Judit.MolnarSansum@glasgow.ac.uk, Lea.Kreinin@glasgow.ac.uk

${ }^{3}$ Department of Regional Geography, Institute of Geography and Earth Sciences, Eötvös Loránd (ELTE) University, H-1117 Budapest, Pázmány Péter sétány 1/C. E-mail: agria@gmx.net

${ }^{4}$ http://www.un.org/en/development/desa/population/migration/data/estimates2/estimates15.shtml

${ }^{5}$ www.unhcr.org/576408cd7
} 
in the world are not international migrants. However, communities everywhere and people's way of life are changed by migration, and we therefore live in the age of migration (Castles, S. and Miller, M.J. 2009).

Different types of problems arise when studying international migration. There are two main issues: who are the immigrants (refugees, asylum seekers, economic migrants etc.) and how many are there in the receiving countries. Geographers especially are also interested in detecting immigrants' and refugees' countries of origin or the departure countries. These questions are common among scholars investigating immigration. KING and ÖBERG stated that the terms used for immigrants in different countries often have different meanings which are specific to those countries (KING, R. and ÖBERG, S. 1993). FASsMANn and Münz pointed out other problems - apart from the complications around definitions of terms - like the poor quality of data or historical issues around citizenship and the registration of immigrants (FASSMANN, H. and MüNZ, R. 1994). As KING and ÖвеRg concluded, these issues "make any study of contemporary European migration very difficult, especially regarding statistical data" (KING, R. and ÖBERG, S. 1993, 2 ) and 23 years later these problems still apply to the study of immigration.

\section{Short overview of the history of migration studies and theories}

The number of the publications about international migration is enormous; it is impossible to look at and study them all. Here we provide a brief overview of the main theories of migration particularly from a geographical perspective. Geographers made a significant contribution to the study of migration (Robinson, V. 1996). "Migration is clearly a space-time phenomenon, defined by thresholds of distance and time; this makes it intrinsically geographical" (KING, R. 2011). In his paper, KING selected four geographers' works which contributed to migration theory the most significantly: Raveinstein, Zelinsky, Mabogunje and Hägerstrand, arguing that they had an influential effect on other scholars' work on this issue (KING, R. 2011).

Migration is a very complex process. Richmond states that theories of migration can be classed according to the level of analysis as macro (focusing on migration streams, describing the conditions and the outcome of migration) and micro (socio-psychological and personal adaptation studies) (RICHMOND, A.H. 1988). According to MASSEY and her colleagues, the study of international migration has often fallen into two rather separate bodies of social scientific investigation: 1) research on the determinants, processes and patterns of migration, and, 2) research on the ways in which migrants become incorporated into receiving societies (MAssey, D. et al. 1993). CAstLEs and MilLer argue that this distinction is artificial, and detrimental to a full understanding of the migratory process. In their view, the second area should be understood more broadly as the way in which migration brings about change in both sending and receiving societies (CASTLES, S. and Miller, M.J. 2009).

Determinants, patterns and processes of migration

Migration studies started to develop at the end of the $19^{\text {th }}$ century. It is an interdisciplinary field that encompasses history, geography, political science, ethnology, anthropology, demography and sociology. This is reflected in the myriad of different approaches and methods of research. Probably the economic theories of migration are the most well-known of all. One of the dominant and the most simplistic amongst them is the so-called neoclassical theory, or pushpull theory, which has its antecedents in the work of Ravenstein (CAstles, S. and Miller, M. J. 2009). According to this theory, migration is governed by unfavourable conditions (poverty, oppression) which push people out and favourable conditions in another location (better economic opportunities) which pull people in. 
This theory was widely criticised and researchers altered this migratory model by adding a wider range of factors to the migration process (CAstles, S. and Miller, M. J. 2009). In the late 1970s, Piore introduced a new approach, the dual labour theory, which considers a subdivided labour market with two sectors: one has demand for highly educated employees and provides them with high wages, while the other is characterised by low wages and uncertain working conditions (Newbold, K.B. 2014). Stark and Bloom introduced the new economics of labour migration approach and argued that decisions about migration lie in the hands of a family rather than an individual and that the decision-making process is influenced by such other factors as access to credit, remittances and the volatility of local agricultural markets (CAstles, S. and Miller, M.J. 2009; Newbold, K.B. 2014). These theories, however, focus mainly on the economic factors in people's choices.

There are other explanations of international migration trends which attempt to take note of different characteristics and factors. The world systems theory expresses the importance of globalisation in the process of international migration (Newbold, K.B. 2014). CAstles and Miller described this theory as focussing "on the way less developed 'peripheral' regions are incorporated into a world economy controlled by 'core' capitalism" (CAstles, S. and Miller, M.J. 2009, 26). The institutional theory emphasises the role of different institutions and organisations, arguing that they promote or facilitate migration (Newbold, K.B. 2014). The migration systems theory has its background in geography and incorporates both ends of the migratory process as well as the connections or linkages between them (CAstles, S. and Miller, M.J. 2009). The social network theory concerns mechanisms for the perpetuation of international migration and focuses on microlevel elements, like families, friends and immigrant communities (Newbold, K.B. 2014).

As the migration process is very complex, in recent years these theories have been de- veloped further, becoming more sophisticated approaches that take into consideration age, education, family status and other important personal characteristics which can influence people's decisions and therefore facilitate or retard migration.

A big shift has also occurred in terms of viewing the interaction of migratory processes with different social spaces. Whereas previously migration was looked at as a rather directed movement with a point of departure and a point of arrival, it is now increasingly understood as an on-going movement between two or more social spaces or locations. This is captured by the terms transmigrant and transmigration. "Transmigrants are people who belong to more than one world, speak more than one language, inhabit more than one identity, have more than one home, who have learned to negotiate and translate between cultures, and who, because they are irrevocably the product of several interlocking histories and cultures, have learned to live with, and indeed to speak from, difference. They speak from the 'in-between' of different cultures" (Inda, J.X. and Rosaldo, R. 2002).

Types of migratory movement can be forced and voluntary, long-term and shortterm (Richmond, A.H. 1988). As already mentioned, migration can be planned as only short-term for a certain period, but may also last longer and sometimes there will be no return to the country of origin (LADos, G. and Hegedús, G. 2016). The duration of migration may be difficult to determine, as in the beginning the migrants may consider it only temporary but then change their mind. This happened in North America and Europe with the temporary workers of the 1960s, who later settled down and brought their families over, forming new ethnic minorities (VAN HEAR, N. 2010). In some cases, people still consider their migration temporary even though they have been living somewhere for many decades. Sometimes there is no possibility of returning. This leads us to the next types of migration voluntary and involuntary (forced) migration.

According to some researchers, there is a fundamental difference between whether 
people themselves decide to migrate (for economic reasons) or are forced to leave their homes due to war or persecution. Others, however, complicate this distinction and do not distinguish between voluntary and involuntary migration (FISCHER, P.A. et al. 1997; Jürgenson, A. 2011). Fischer and his colleagues argue that involuntary migrants try to minimise their risks rather than maximise their utility (FISCHER, P.A. et al. 1997). VAN Hear, in addition to these, brings in one more type of migration - mixed migration, which is the intersection between voluntary and forced movement. It is argued that migration can be mixed in several senses: motivations about making the decision to move; travelling with others in mixed migratory flows; motivation changes en route; ending the journey in mixed communities (VAn Hear, N. 2010). The previous study shows very clearly that it is, in many cases, difficult to distinguish between voluntary and forced migration and that there is no agreement on this dichotomy amongst migration researchers.

\section{Migrant experiences of incorporation into receiving societies old models and transnationalism}

The second, larger field of migration studies is research on the ways in which migrants become incorporated into receiving societies. The focus here is on the receiving society and the migrants' personal settlement experience. This field started to bloom as an area of academic research after World War II, especially in the United States, where the rapidly growing migrant communities in cities were intensely researched. These communities were looked at as enclave societies with relatively intact cultures. The traditional "melting pot ideology" emphasised acculturation, treating minority cultures in urban contexts as conservative, maladaptive residues, 'survivals' resisting cultural change to the dominant white mode (LewIs, W.A. 1978). In migration research, the assimilation model was prevalent from the beginning of the $20^{\text {th }}$ century until the 1990s. It predicted an eventual blend- ing of immigrant strains into a single novel amalgam (Zelinsky, W. and LeE, B.A. 1998). According to the assimilation model, newer and newer waves of immigrants all start from low positions, and as they gain better status in society they will be absorbed into the dominant community (MAssey, D.S. et al. 1993).

The second half of the $20^{\text {th }}$ century provided more and more examples of deficiencies in the assimilation model. The segmented adaptation theory is based on three factors: 1) the nature of migration to the host country (forced or voluntary); 2) the resources that immigrants bring; and 3) the host country's reception (Portes, A. and Zhou, М. 1993; Sкор, E.H. 2001). Woltman and Newbold consider the segmented assimilation theory ("discrimination and unequal opportunities affect processes of adaptation") "in the context of how the adaptation of Cuban émigrés differs along lines of race" (Woltman, K. and Newbold, K.В. 2009). Sкор argues the same issue in respect of the adaptation of Mariel exiles (Sкор, E.H. 2001). Zelinsky and Lee pointed out the impact of new technologies on immigrants' socio-spatial behaviour - innovations revolutionised the late $20^{\text {th }}$ century's communication, providing new prospects for people to maintain contact, create and keep their social networks - envisaging a mosaic of self-sustaining ethnic communities instead of a melting pot (ZeLinsky, W. and LeE, B.A. 1998). They argue that this approach can cope with the diversity of immigrants and they characterise it as a pluralist approach. A study of immigrants in London has shown that these two models can co-exist in the same city - 'assimilationism', being played out by the Caribbeans, and pluralism as the path being followed by Bangladeshis (РеACH, C. 1968; ZeLinsky, W. and LeE, B.A. 1998).

\section{Brief history of international migrations concerning Europe}

As we may learn from the Atlas of Migration (KING, R. et al. 2010), migration is not a new phenomenon in human history, but rather 
an "ever-present theme". Earlier in time when national territories were not always defined by hard borderlines "the distinction between internal and international migration is meaningless. A more appropriate distinction is that between short- and long-distance movement" (Jones, H.R. 1990, 229). Many migration periods have shaped Europe's social, economic, and political-geographic characteristics through human history. These events can be seen and analysed via different narratives: ecological, pioneering, Marxist and diaspora narratives (KING, R. et al. 2010).

\section{Before 1945}

Early modern humans migrated from Asia to Europe during the Upper Paleolithic. During the first millennium $\mathrm{BC}$, the migration of Celtic peoples in continental Europe and the expansion of the Ancient Greeks in the Mediterranean region were important phenomena. At the time of the Roman Empire (from $1^{\text {st }}$ century $\mathrm{BC}$ to $5^{\text {th }}$ century $\mathrm{AD}$ ), there was substantial intercontinental migration (affecting Europe, Asia and Africa), exemplified by the dispersion of the Jews throughout the empire in the aftermath of the Jewish-Roman wars $\left(1^{\text {st }}-2^{\text {nd }}\right.$ centuries $\left.A D\right)$. At the time of the Roman Empire and especially after its collapse, almost the whole of Europe was affected - in the form of a military invasion - by the migrations of the Germanic tribes $\left(2^{\text {nd }}-5^{\text {th }}\right.$ centuries). Successive migrations of various peoples then followed (within Europe and often originating in Asia): Huns $\left(4-5^{\text {th }}\right.$ centuries), Slavs ( $5-7^{\text {th }}$ centuries), Avars (6-7 $7^{\text {th }}$ centuries), Turkic Bulgars $\left(7^{\text {th }}\right.$ century), Hungarians (7-9 ${ }^{\text {th }}$ centuries), Moors (Islamic Arabs and Berbers from the Maghreb, 8-9 $9^{\text {th }}$ centuries), Cumans-Kipchaks, Mongols-Tatars $\left(11-13^{\text {th }}\right.$ centuries).

Intercontinental migration was particularly significant in the first centuries of the Ottoman (Turkish) Empire (1299-1922), as it extended its control to Southeast Europe and North Africa. Such migration mainly took the form of Turkish colonisation in Europe and the deportation of European slaves to Asia and Africa. During this period (14-15 ${ }^{\text {th }}$ centuries), the Romani people (Gypsies) of Indo-Aryan ethnic origin migrated from Asia and settled in Europe. The period also saw the expulsion or emigration of Jews from Western Europe and the Iberian Peninsula, most of whom migrated - in the form of West-East migration - to Eastern and Southeast Europe (GILBERT, M. 2010). Later, $\left(16-17^{\text {th }}\right.$ centuries, during the Reformation and Counter-Reformation) religious wars were the primary cause of international migration within Christian Europe. After the geographical discoveries and as part of the process of colonisation (mostly from the $16^{\text {th }}$ to $20^{\text {th }}$ centuries), the most important international migration era was the New World: the Americas, Sub-Saharan Africa, Australia and Oceania "embracing some 55-65 million emigrants from Europe between 1820 and 1930, or about one-fifth of Europe's population at the beginning of the period" (Jones, H.R. 1990).

Until the end of World War II, emigration was a dominant phenomenon in Europe's migration, but there were significant intraEuropean spatial movements as well. Labour migration, which has been driven by industrialisation, was significant. Britain, Germany and France were the most important receiving countries. "By 1851 there were over 700,000 Irish in Britain ... [and] 120,000 Jews, who came as refugees from the pogroms of Russia between 1875 and 1914 (Castles, S. and Miller, M.J. 2009). Germany had almost a million foreign workers in 1907 from Poland, Belgium, Italy, the Netherlands and other countries across Europe (CAstles, S. and Miller, M.J. 2009). France had even more foreign workers; by 1911 their number reached 1.2 million, constituting 3 percent of the total population (CAstles, S. and Miller, M.J. 2009). These immigrants had an essential role in the industrialisation of these countries.

World War I changed the situation in Europe. During the war, many immigrants returned home, and there was a shortage of labour. France responded to this challenge by recruiting workers and even soldiers from the colonies: North Africa, West Africa, Indo-China and 
China. Their numbers were altogether about 225,000 (CAstles, S. and Miller. J.M. 2009).

In the interwar period the number of foreign workers (and immigration) was reduced due to the economic crisis and increased xenophobia. At that time, "France was the only Western European country to experience substantial immigration" (CAstLes, S. and Miller. J.M. 2009), and some French migrants returned from North Africa. World War II and the military operations brought about large scale migration with huge number of refugees, displaced people and forced foreign labourers. In the post-war period, a new era began in Europe with fresh waves of international migration.

\section{Since 1945}

In the aftermath of World War II, millions of people were relocated, forcibly or voluntarily, in consequence of international and bilateral agreements (OHLIGHER, R. et al. 2003). Between 1944 and 1947, 15.2 million Germans were forced to leave their homes under population transfers or through evacuation and flight (Kulischer, E.M. 1948). Europe still had a net loss of 2.7 million migrants between 1950 and 1959, and the shift to a continent of immigration only occurred in the 1970s (BADE, K.J. 2003) despite the mass migration of guest workers to Western Europe. Although many of these guest workers were migrants from other European countries (Ireland, Finland and the Southern European countries), significant numbers of them arrived from North Africa and Turkey (Bade, K.J. 2003; Castles, S. and Miller, M.J. 2009). In 1970-1971, the foreign resident population in 18 Western European countries comprised almost 11 million people, and this number had risen to 18.4 million by 1990-1991 (FAssmanN, H. and Münz, R. 1994). During the post-war decades, there was also significant return migration of former colonists to their home countries after the colonies became independent (CAstles, $S$. and Miller, M.J. 2009). BAdE estimates that, taken together, return migration and immigration involved between 5.5 and 8.5 million people in Europe after decolonisation (BADE, K.J. 2003). After the 1973 economic crisis, the character of immigration changed. In the Western European countries, net migration rates decreased as soon as these countries ceased recruiting foreign workers (Figure 1), and family-type immigration became more frequent (KING, R. and ÖвеRG, S. 1993; CASTLES, S. and Miller, M.J. 2009).

In the 1980s, the Eastern Bloc countries (in particular the Soviet Union and the German Democratic Republic) also recruited contract workers from Vietnam, albeit they were called trainees (CAstles, S. and Miller. J. M. 2009). Furthermore, since the 1960s students and highly skilled workers have been moving to Europe, and the continent has also provided home for refugees from troubled Asian and African countries (CAstLes, S. and MilLER. J.M. 2009).

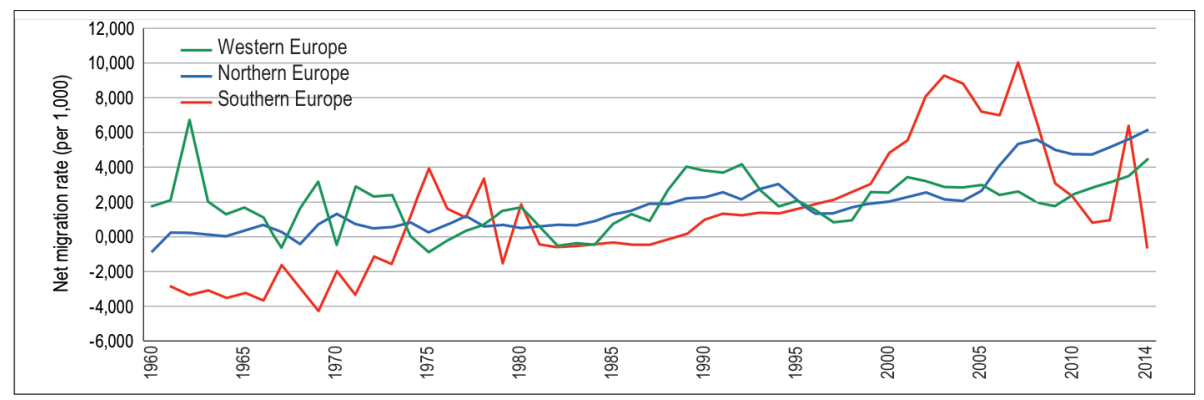

Fig. 1. Net migration rate in Northern, Western and Southern Europe between 1960 and 2014. Source: http://ec.europa.eu/eurostat/data/database http://ec.europa.eu/eurostat/data/database 
The collapse of the Soviet Union resulted in the large-scale migration of ethnic Russians and other ex-Soviet citizens (RoBERTSON, R.L. 1996). In the meantime, "a new Eurasian migration system has emerged. Migrants come from Russia's own distant provinces, such as the Russian Far East and Eastern Siberia, from its 'near abroad' countries - the successor states in Central Asia and the Caucasus - and from 'far abroad' countries such as China, Turkey and Vietnam" (KING, R. et al. 2010). The estimated numbers of these workers in Russia were 8 million, 2 million with and about 6 million without permission in 2007 (KING, R. et al. 2010).

In the 1980s and especially after the fall of the Berlin Wall, European migration experienced a rapid change again: many Southern European states became receiving countries, and net migration started to grow again in the Western European countries (Figure 1). Creating a single market and the enlargement of the European Union, all contributed to the changing features of European immigration. "This geopolitical shift coincided with the acceleration of economic globalization, as well as an increase in violence and human rights violations in Africa, the Middle East, Asia and Latin America" (Castles, S. and Miller, M.J. 2009). From the beginning of the 2000s, net migration increased rapidly as "economic globalization continued to increase commercial and employment opportunities" (CAstles, S. and Miller, M.J. 2009). Many Central and Eastern European countries became receiving countries after 1990. With EU membership, however, the historical East-West migration resumed. There are no reliable data about how many EU citizens from the former communist countries are working in the more developed areas of the EU. Still, Eurostat data indicate that in 2015, 4.78 million EU citizens from the former communist countries were residing in other EEA states and in Switzerland, whereas only 312,000 EU citizens from the rest of the EEA and Switzerland were living in the post-communist EU member states (Figure 2).



Fig. 2. Number of EU citizens from the former communist countries in the rest of EEA and Switzerland; and number of citizens from the rest of the EEA and Switzerland in the post-communist EU countries between 2006 and 2015). Source: http://appsso. eurostat.ec.europa.eu/nui/show.do?dataset=migr pop3ctb\&lang=en

According to UN data, the international migrant stock of non-European immigrants has increased significantly since 1990, from almost 20 million to 35.3 million. In 2015 the five largest non-European resident populations were in Russia (6.9 million), UK (5.4 million), France (5.1 million), Germany (4.8 million) and Spain (3.6 million) (Figure 3).

Immigration to Europe has been characteristic and significant since World War II, but the countries of origin of the migrants have not been constant. Since 1990, the largest numbers of immigrants to Europe have come from Kazakhstan, Turkey, Morocco, Algeria and Uzbekistan, but many people have also come from India, China and Pakistan. In the case of the EEA countries and Switzerland, the greatest numbers of new arrivals have come from Turkey, Morocco, the Russian Federation, Algeria and India.

\section{Allochthonous minorities and foreign-born populations resulting from international migration}

As a consequence of international migration that occurred in the second half of the $20^{\text {th }}$ century, Europe experienced sharp increases in the absolute and relative population size of the so-called allochthonous ("newcomer") 


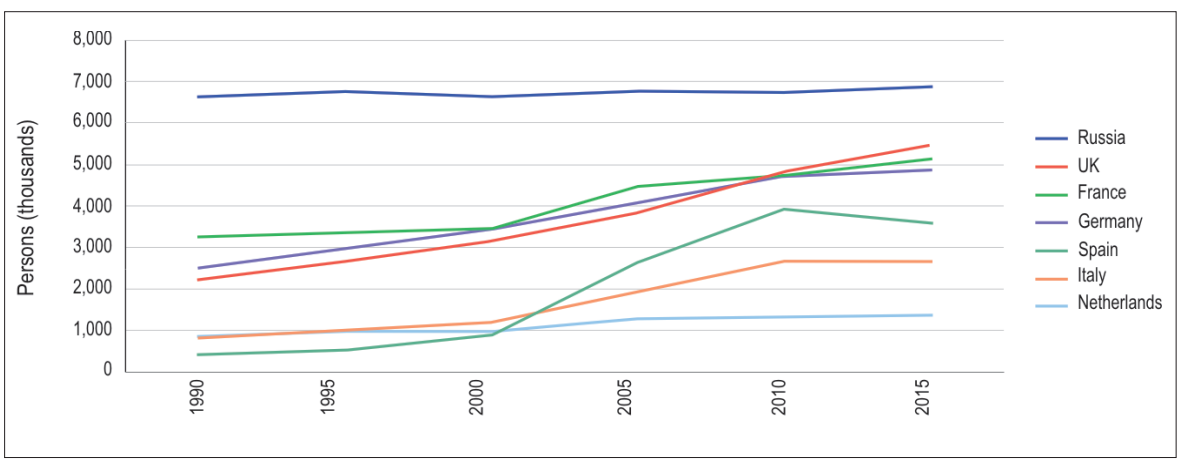

Fig. 3. Non-European migrant stock with the largest number of immigrants in the European countries between 1990 and 2015. Source: http://www.un.org/en/development/desa/population/migration/data/estimates2/estimates15.

shtml, http://www.un.org/en/development/desa/population/migration/data/estimates2/estimates15.shtml

minorities and the foreign-born population. In general, cross-border migration means the arrival of people who differ from the receiving country's population in terms of ethnicity, language, religion and cultural traditions, but this is not always the case. Indeed, in recent decades, many millions of people belonging to the European titular nations have migrated to the "kin-country" from foreign countries - either because of a political-economic crisis or due to ethnic discrimination, examples are: Germans ("Spätaussiedler") moving from Eastern Europe to Germany; Russians and Ukrainians from the ex-Soviet republics to Russia and Ukraine; Serbs and Croats from ex-Yugoslav republics to Serbia and Croatia; Hungarians from the neighbouring countries to Hungary etc. Over the past half a century, there has been a tenfold increase in the number of people (currently 67 million) belonging to the so-called allochthonous minorities, which are communities that have been present in a country for less than a hundred year (Table 1).

These new immigrant groups have settled principally in Western Europe, where, in 2011, their share in the total population exceeded 15 percent. This particularly applies to those Western European countries (usually former colonial powers) that have the highest income and living standard as well as the best social welfare systems i.e.
France $^{6}$, Germany ${ }^{7}$, the United Kingdom ${ }^{8}$ (16-10 million people in the allochthonous minority population), Spain ${ }^{9}$, Italy ${ }^{10}$ and the Netherlands ${ }^{11}$ (6-3 million people in the allochthonous minority population). At the time of the 2011 censuses, the allochthonous minorities already included a large number (17 million) ${ }^{12}$ of Muslims (Arabs, Turks, Pakistanis, Bangladeshis and Albanians), whose numbers were particularly high in France, Germany, the United Kingdom and Italy (BоттLIK, Z. 2009). A significant difference between the eastern and western halves of Europe pertains to the relative sizes of the allochthonous minorities and the foreignborn populations. The percentages of both are very high in Western Europe, but the size of the allochthonous minority population relative to the foreign-born population is higher in the West (due to the presence of the locally born descendants of the immigrants) and

${ }^{6}$ Arabs, Italians, Portuguese, Spaniards, Chinese, Turks, Poles.

7 Turks, Poles, Italians, Romanians, Greeks, Croats, Serbs, Albanians, Russians.

8 Indians, Pakistanis, Bangladeshis, Germans, USAmericans, Jamaicans, South Africans.

${ }^{9}$ Romanians, Moroccans, Latin Americans, British, Italians, Germans.

${ }^{10}$ Romanians, Arabs, Albanians, Chinese, Ukrainians.

${ }^{11}$ Turks, Moroccans, Indonesians, Surinamese.

12 http://www.pewforum.org/2011/01/27/tablemuslim-population-by-country/ 
Table 1. Allochthonous minorities and foreign-born population in Europe (1960, 2011)

\begin{tabular}{l|c|c|c|c|r|r}
\hline \multirow{2}{*}{\multicolumn{1}{c}{ Region }} & \multicolumn{2}{|c|}{ allochthonous minorities } & $\begin{array}{c}\text { foreign-born } \\
\text { population }\end{array}$ & allochthonous minorities & $\begin{array}{c}\text { foreign-born } \\
\text { population }\end{array}$ \\
\cline { 2 - 7 } & \multicolumn{3}{|c}{ in thousands } \\
\cline { 2 - 7 } & 1960 & 2011 & 2011 & 1960 & 2011 & 2011 \\
\hline Western Europe & 6,191 & 63,364 & 51,018 & 1.9 & 15.3 & 12.4 \\
Eastern Europe* & 360 & 3,311 & 19,029 & 0.1 & 1.2 & 6.6 \\
Europe & 6,528 & 66,676 & 70,047 & 1.2 & 9.6 & 10.0 \\
\hline
\end{tabular}

*Post-communist countries of Europe, including the European parts of Russia. Sources: Calculated by K. Kocsis based on BRUK, S.I. and ApEnchenko, V.S. ed. 1964, census data (ethnicity, citizenship, foreign-born population, migration) and estimations of ethnic communities. Foreign-born population: http://data.un.org/ Data.aspx?d=pop\&f=tableCode $\% 3 \mathrm{~A} 44$

lower in the East, where a large proportion of foreign-born immigrants belong, ethnically, to the titular nations. During the period under discussion, international migration has evidently been characterised by the arrival of "home comers" in Eastern Europe and of "exotic newcomers" in Western Europe.

Between 2011 and 2015, the ratio of foreignborn persons in the European Economic Area ${ }^{13}$ and Switzerland - the main destination areas for international migration in Europe increased from 10.5 percent to 10.7 percent. In 2015, the share of foreign-born population was particularly high in the richest and smallest countries: Liechtenstein $(63.7 \%)$, Luxembourg (44.2\%) and Switzerland $(27.4 \%)$. Countries with lowest shares of foreign-born population were Romania (1.4\%), Poland (1.6\%) and Bulgaria (1.7\%) (Figure 4). The corresponding figure in Hungary was $4.8 \%$, mainly due to Hungarians who moved to the country from the ethnic Hungarianinhabited areas of the adjacent countries.

People born outside the EU accounted for 64 percent of the total foreign-born population in the area under inquiry (the EEA and Switzerland). The number of people born outside the EU is particularly high (4-6 million) in each of the following countries: Germany, France, the United Kingdom, Italy

${ }^{13}$ European Economic Area (EEA): the European Union's 28 member states and Iceland, Liechtenstein and Norway. For the purposes of this study, we have also included Switzerland, an EFTA member that is not an official member of the EEA but which is tied to it by bilateral treaties. and Spain. The major groups of people born outside the EU are the Turks in Germany, the Indians and Pakistanis in the United Kingdom, the Algerians and Moroccans in France, the Moroccans, Ecuadorians and Colombians in Spain, and the Albanians and Moroccans in Italy. This population percentage is negligible $(0.5-1.7 \%)$ in the former communist countries lying between the Baltic and Black seas (Slovakia, Romania, Bulgaria, Poland and Hungary).

As far as Estonia, Latvia and Croatia are concerned, politically motivated migration (rather than economic attraction) explains the relatively high share of people born outside the EU. In the case of Estonia and Latvia, the major factor is the politically motivated settlement of Russians (with smaller numbers of Belarusians and Ukrainians), who came from other parts of the Soviet Union between 1945 and 1989. In Croatia's case, the high percentage of people born outside the EU (12-14\%) is due to the influx of ethnic Croatian refugees from Bosnia and Herzegovina and Serbia at the time of the Yugoslav wars (1991-1995).

\section{European migrant crisis: motivations and sending countries}

After the decline in the waves of migration caused by the collapse of the European communist regimes ${ }^{14}$, the year 2015 saw - partly

\footnotetext{
${ }^{14}$ For example, the Croatian and Bosnian wars (1991-1995) and the Kosovo Crisis (1990-1999).
} 


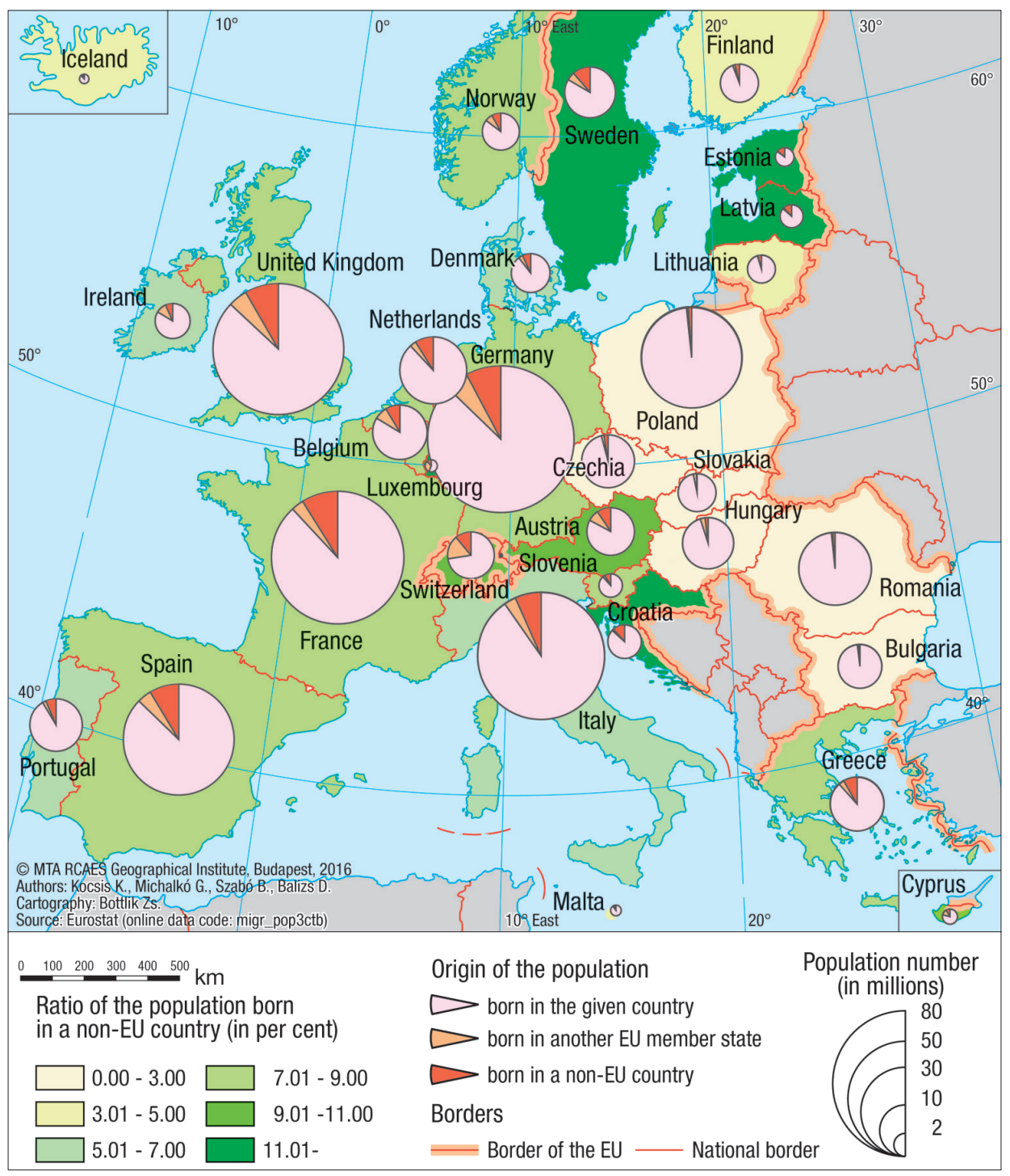

Fig. 4. Foreign-born population in the countries of the EEA and in Switzerland (1 January, 2015). Source: see the map

in consequence of the events of the "Arab Spring" of 2011 - a dramatic increase in illegal immigration, as asylum seekers reached Europe from neighbouring areas in Asia and Africa (Figure 5).

In 2015, almost 1.3 million $^{15}$ new asylum applications were submitted in the EU. This

\footnotetext{
${ }^{15}$ By the end of September 2016, 598,826 new asylum applications had been registered.
}

was more than double the previous record for such applications, which had been recorded in 1992 (after the outbreak of the Bosnian war). The question arises: How does the current migration crisis differ from earlier such crises? The following possible answers can be formulated: an unprecedented number of migrants/refugees arrived in the EU (the highest number since World War II); the migrants 


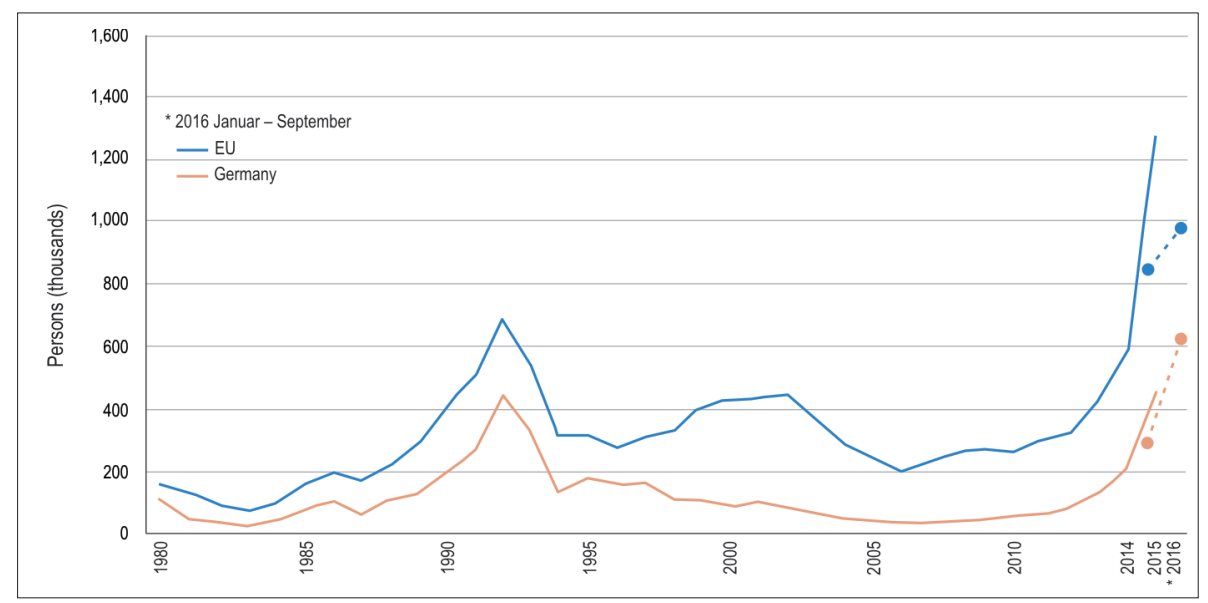

Fig. 5. Change in number of first time asylum seekers in the EU and Germany (1980-2016). Source: http://popstats.unhcr.org/en/asylum_seekers

arrived predominantly by sea and from very great distances; the earlier crises were more geographically concentrated in terms of both the countries of origin and the countries of destination; the motives for migration and the national (ethnic) composition of the migrants are far more complex and diverse now than they used to be; today's migrants target - in a far more conscious fashion than did their predecessors - the Western European countries with their stronger economies and higher living standards; several European countries at the forefront of events were subjected relatively rapidly and unexpectedly to substantial migration pressures (e.g. Italy, Greece, Hungary, Croatia). ${ }^{16}$

There are numerous global and regional causes of migration into Europe and the sudden acceleration of such migration. Among these factors, emphasis should be given to the social and demographic factors, in particular intercontinental demographic imbalances, namely the fact that the European countries find themselves in the fourth and fifth (the low stationary and declining) stages of the demographic transition. These stages are characterised by population stagnation/de-

\footnotetext{
${ }^{16} \mathrm{http}: / /$ www.oecd.org/els/mig/Is-this-refugee-crisisdifferent.pdf
}

crease, low birth rates, and an ageing population (KÁČERovÁ, M. et al. 2014). In contrast, the Afro-Asian regions (Muslim Africa ${ }^{17}$ and Southwestern Asia ${ }^{18}$ ) neighbouring Europe, which are inhabited predominantly by Muslims, are in the second and third (early and late expanding) stages of the demographic transition: dynamic population growth (in some locations, a veritable "population boom"), high birth rates, falling death rates, and a rapid increase in the percentage of young people of working age who are most inclined to migrate (Figure 6).

Between 1950 and 2015, the population of Europe grew by a third (owing basically to immigration into Western Europe), whereas in the same time interval Muslim Africa and SW Asia experienced an almost fivefold population increase. In Syria, which is currently the principal source of immigration to Europe, the population increased by a factor of six during this period, while in Iraq

${ }^{17}$ Muslim Africa: countries in Africa with majority Muslim populations: Algeria, Burkina Faso, Chad, Djibouti, Egypt, Eritrea, Gambia, Guinea, Guinea Bissau, Libya, Mali, Mauritania, Morocco, Niger, Senegal, Sierra Leone, Somalia, Sudan, Tunisia, Western Sahara.

${ }^{18}$ Southwesten Asia: Asian countries of the Middle East, Caucasus countries, Afghanistan and Pakistan. 


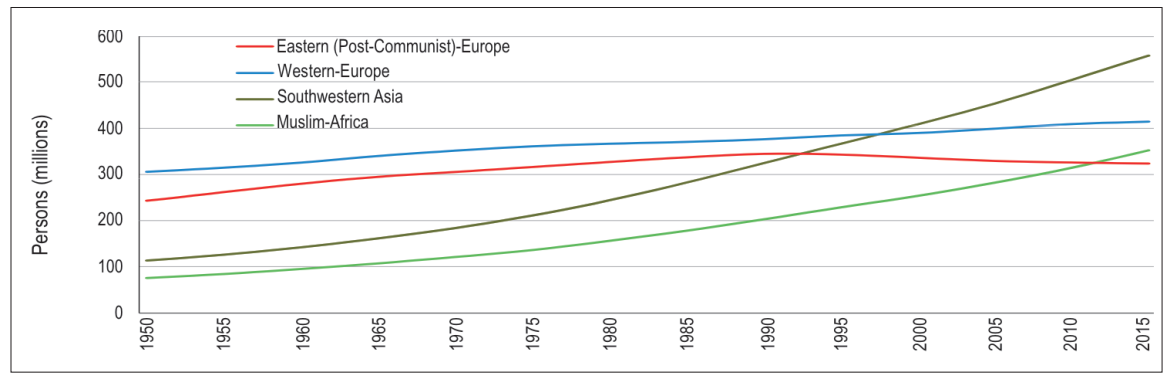

Fig. 6. Change in population number of selected Eurasian and African macroregions (1950-2015). Source: https://esa.un.org/unpd/wpp/Download/Standard/Population/

the population increased by a factor of 5.4. In several of the Afro-Asian countries under inquiry, the societal motives for migration include a very high level of ethnic and religious diversity, which has been and remains a constant potential source of conflict. In this regard, the most unstable countries in SW Asia are: Afghanistan, Iran, Iraq, Lebanon, Pakistan, Syria and Turkey. ${ }^{19}$

In the source areas of intercontinental migration, the local economy, GDP growth, and job creation could not keep up with the population boom and demographic growth described above (Figure 7). Coupled with other economic factors (e.g. the global economic and financial crisis), all this has resulted in a rapid rise in unemployment and, in the first instance, in growing domestic (rural $\rightarrow$ urban) migration.

Natural factors (e.g. climate change, desertification, water scarcity, and other natural hazards) have exacerbated the migration process. Most of the source areas for AfroAsian migration to Europe lie in the arid and semi-arid regions of dry climate zone, where average annual precipitation is less than 250

\footnotetext{
${ }^{19}$ Afghanistan: 15\% Shia Muslims; 42\% Pashtun, 27\% Tajik, 9\% Uzbek, 8\% Hazara, 4\% Aimaq, 3\% Turkmen; Iran: 16\% Azerbaijanis, 10\% Kurds, $6 \%$ Lurs, 2\% Turkmens; Iraq: 65\% Shia and 37\% Sunni Muslims, 1\% Christians; 20\% Kurds; Lebanon: 27-27\% Sunni and Shia Muslims, 40\% Christians, 5.6\% Druze; Pakistan: 10-25\% Shia Muslims; 45\% Punjabi, 15\% Pashtun, $14 \%$ Sindhi, $8 \%$ Saraiki, $8 \%$ Muhajirs, $4 \%$ Balochi; Syria: 13\% Shia Muslims, 10\% Christians, 3\% Druze, 10\% Kurds; and Turkey: 18\% Kurds. https://www.cia. gov/library/publications/the-world-factbook/
}

mm (Siegmund, A. and Frankenberg, P. 2013). Studies on climate change and desertification in the Middle East and on the socio-political effects of such phenomena have shown that the changes are adding to the aridity of the region and that increasing greenhouse gas emissions are significantly influencing climate change in the Eastern Mediterranean region (GLEICK, P.H. 2014, Kelley, C.P. et al. 2015). In Syria, desertification and poor groundwater management have led in recent years to significantly lower levels of agricultural production. A three-year drought occurred between 2007 and 2010, which was unprecedented since climate records began. Around half a million workers who were previously engaged in agriculture have moved to urban areas, where tensions increased steadily in the years prior to the outbreak of civil war.

In addition to the social, economic and natural causes outlined above, global and regional political factors (global political rivalries, local power changes, wars $)^{20}$ also

\footnotetext{
${ }^{20}$ Sudanese civil wars (since 1955), conflicts, wars in the Horn of Africa (since 1961), Six-Day War (1967), Yom Kippur War (1973), Lebanese Civil War (1975-1990), Kurdish-Turkish Conflict in Turkey (since 1978), Iranian Islamic Revolution (1978-1979), Iran-Iraq War (1980-1988), Gulf War (1990-1991), Iraq War (20032011), Soviet-Afghan War (1979-1989), Civil wars in Afghanistan (1989-1992-1996-2001), American/ NATO War in Afghanistan (2001-2014), "Arab Spring": Tunisian Revolution (2010-2011), Libyan Civil War (2011), Egyptian Crisis (2011-2014), Bahraini Uprising (2011), Yemeni Revolution (2011) and civil war (since 2015), Syrian Civil War (since 2011).
} 


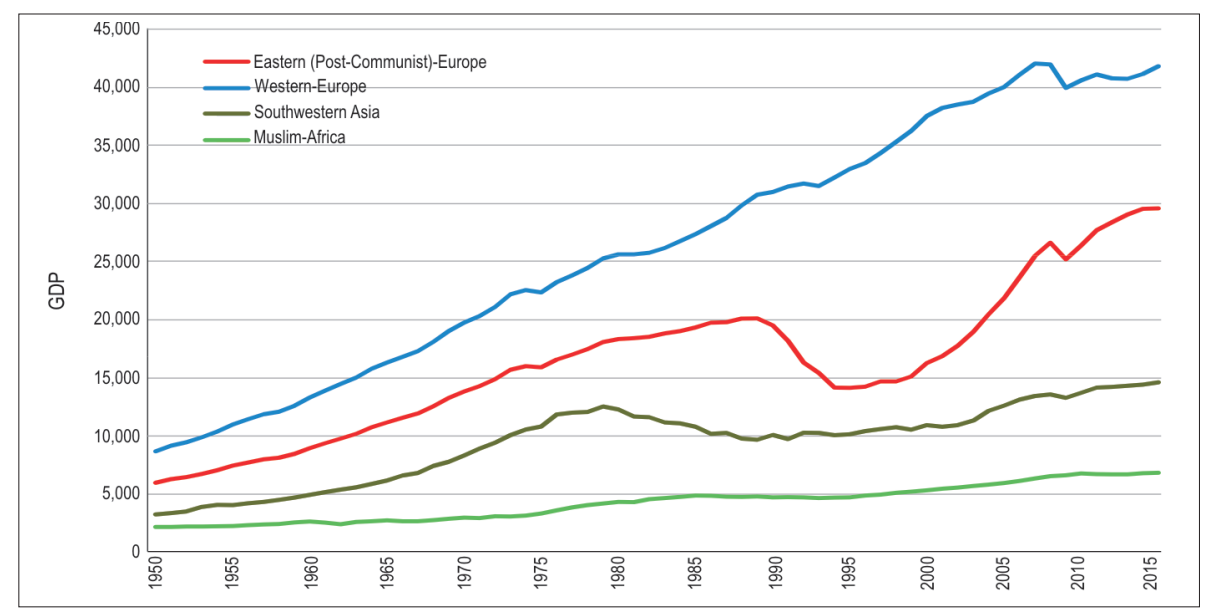

Fig. 7. Change in per capita GDP* in selected Eurasian and African macroregions (1950-2015). *GDP, in 2015 USD converted to 2015 price level with updated 2011 PPPs. Source: https://www.conference-board.org/data/ economydatabase/index.cfm?id=27762

lie behind international migration. As far as the present European migration crisis is concerned, the most influential factor has been the so-called "Arab Spring" 21 (20102012). The associated revolutionary events had several triggers: the global economic crisis that began in 2008, the gap between demographic and economic growth, social inequality, unemployment, poverty, and increasing corruption. The "Arab Spring" led to civil war in Libya and Syria and to the fall of governments in Tunisia, Egypt and Yemen. In most cases, democratisation did not follow the overthrow of the authoritarian regimes. Instead, extreme Islamist forces came to power, precipitating general chaos and civil war in many places. For this reason, the ensuing period has been called the "Arab Winter". ${ }^{22}$ The political events and wars described above have destroyed much of the local economy. In this regard, the fall in GDP was particularly significant $(-64 \%)$ in Iraq under Saddam Hussein (1979-2003) and in Syria since the outbreak of the civil war (2011) (Figure 8).

\footnotetext{
${ }^{21}$ http://middleeast.about.com/od/humanrightsdemocracy/a/Definition-Of-The-Arab-Spring.htm

${ }^{22}$ http://www.telegraph.co.uk/news/worldnews/ middleeast/9753123/Middle-East-review-of-2012the-Arab-Winter.html
}

The social, economic, natural and political factors underlying migration into Europe are extremely interwoven and mutually reinforcing. This multifaceted and cumulative crisis in the Afro-Asian region is the subject of our investigation. Only in the mid-term is there any hope of mitigating or "resolving" the crisis in the various places. During the European migrant crisis (taking January 1, 2014 as a starting date), in the EEA countries, 1.2 million new asylum applications were made by August 31, 2015 and 2.7 million by August 31, 2016. Southwestern Asia accounted for 61.7 percent of the applications (Figure 9).

In the migration processes described here (which have various motives), the most important source countries were Syria, Afghanistan, Iraq and Pakistan (which account for $27.5 \%, 13.3 \%, 8.7 \%$ and $3.7 \%$ respectively of all applications submitted in the EEA).

Migrants - almost exclusively Muslims - who have left their homes in the conflict region between the Mediterranean Sea and the Himalayas currently constitute the most important source of international migration into the EEA. In the period 2011-2015, the largest increases in the number of persons of concern to the Office of the United Nations 


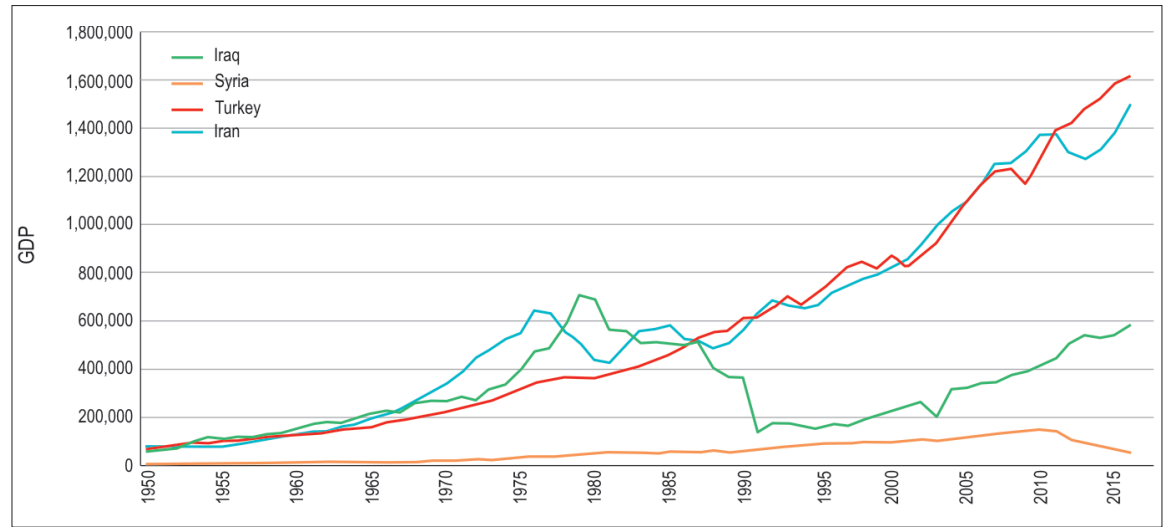

Fig. 8. Change in total GDP* of selected countries in the Middle East (1950-2016, in millions of USD). ${ }^{*}$ GDP, in 2015 USD converted to 2015 price level with updated 2011 PPPs. Source: https://www.conference-board.org/ data/economydatabase/index.cfm?id=27762

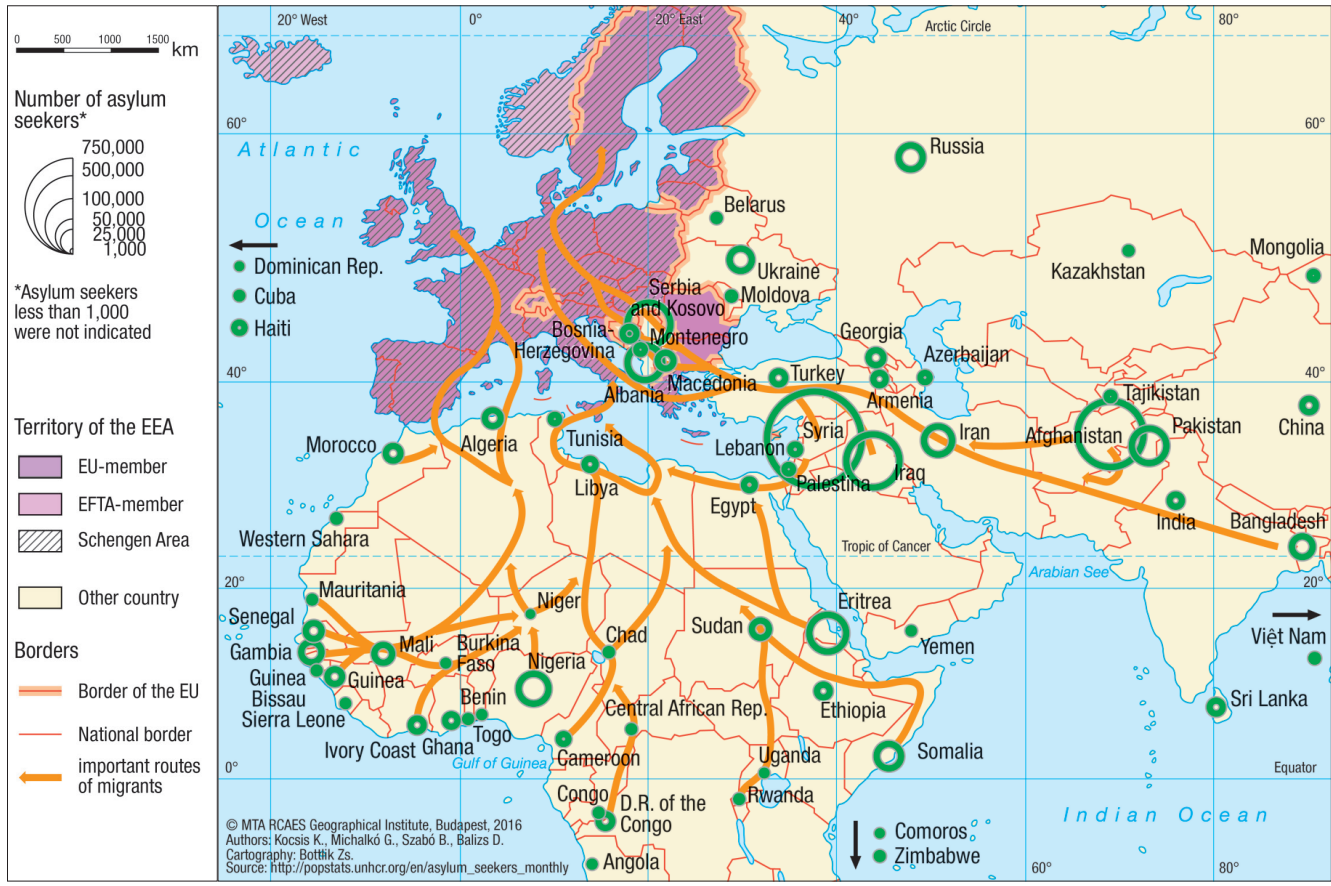

Fig. 9. Asylum seekers in the EEA by country of origin (1 January, 2014 - 31 August, 2016). Source: see the map

High Commissioner for Refugees (UNHCR, refugees, asylum seekers, internally displaced persons, stateless persons etc.) were recorded in Syria (from 1 million to 6.7 million) - owing to the Syrian civil war and the war against
ISIS (Islamic State of Iraq and Syria) -, in Iraq (from 1.7 million to 4.7 million), in Turkey (from 36,000 to 2.8 million), in Afghanistan (from 1.5 million to 1.8 million) - owing to the Afghanistan wars that have been raging 
intermittently for almost a century- and in Pakistan (from 2.8 million to 3.4 million). ${ }^{23}$

Since the outbreak of the Syrian civil war in 2011, there has been a sharp increase in the number of Syrians fleeing to the neighbouring countries of the Middle East. The most recent data of the $\mathrm{UNHCR}^{24}$ indicate that at least 4.8 million Syrians are currently registered in the neighbouring countries (2.8 million in Turkey, 1 million in Lebanon, 655,000 in Jordan, and 229,000 in Iraq). In the period 2011-2016, the lack of any prospect of returning to Syria and the despair of the refugee camps led an increasing number of Syrians to travel to Europe through Turkey and by sea, with a view to seeking asylum in the EEA: 8,000 in 2011, 378,000 in 2015, and 246,000 in 2016 (until August 31). The number of asylum applications made by Syrian, Afghan and Iraqi migrants in Europe peaked in the autumn of 2015 and then declined substantially from the early spring of 2016 after the EU and Turkey signed an agreement to stop irregular migration from Turkey to the EU (Statement of March 20, 2016).

Another significant source of migrants to the EEA is Sub-Saharan Africa (accounting for $16 \%$ of asylum seekers in 2014-2016). Most of the people arriving from this region have come from Muslim areas in Eritrea, Somalia, Nigeria and Gambia. The motives for emigration among these African Muslim migrants are diverse: economic and political factors (demographic boom, unemployment, desertification, natural hazards, repressive regimes, civil wars, ethnic-religious conflicts etc.).

In the EEA, almost 11 percent of asylum seekers (298,000 persons) in the past three years have arrived from the Western Balkans (principally from Kosovo, Albania and Serbia). Most of these people are Muslim Albanians, Roma and Serbs. Most arrivals from the Western Balkans, who are usually treated as economic migrants in the EU, came to Western Europe before the spring of 2015 when Germany introduced stricter reg-

\footnotetext{
${ }^{23} \mathrm{http}$ //popstats.unhcr.org/en/overview

${ }^{24} \mathrm{http}$ ://data.unhcr.org/syrianrefugees/regional.php (17 December 2016)
}

ulations. Factors causing them to leave the Western Balkans were economic problems, general poverty, corruption, dysfunctional government (Bosnia, Kosovo), and the lack of any prospect of EU membership (Kocsis, K. 2001). Most Eastern European asylum seekers arrived from Russia and Ukraine. In the case of the latter, they came mainly from areas affected by the recent civil strife (KARÁcsonyi, D. et al. 2014).

\section{Main routes of the recent international migration into the EEA}

The shortest land routes into the EEA for migrants coming from Africa or Asia lead via the Spanish enclaves on Morocco's Mediterranean coast (Ceuta and Melilla) or via the Turkish-Greek and Turkish-Bulgarian borders. Between 1993 and 2005, to prevent what had initially been a large-scale illegal (mostly Sub-Saharan) African influx, Spain built and expanded border barriers around Ceuta and Melilla. Greece constructed a barrier along its border with Turkey in late 2012, while Bulgaria did so in early 2014.

After the closure of the land routes, the focus of the illegal border crossings switched to routes in the central and eastern Mediterranean. A 2008 agreement between Berlusconi (Italy) and Gaddafi (Libya) represented a temporary solution aimed at stopping African migrants from reaching Italy. The agreement became defunct at the time of the Libyan Civil War (2011). In the chaos of war, Libya, which had no central government and the coutry was regarded as an ideal base for the human traffic networks, became an open gateway to Europe. The number of illegal border crossings into Italy (mostly via the islands of Lampedusa and Malta) increased from 4,500 in 2010 to 170,760 in $2014 . .^{25}$ In addition to this Central Mediterranean route, where there have been several hundred fatalities, in 2015 the focus switched to the

\footnotetext{
${ }^{25} \mathrm{http}$ ://frontex.europa.eu/trends-and-routes/centralmediterranean-route/
} 
Eastern Mediterranean, where people can reach Europe by making a short sea journey (of no more than a few kilometres) from the Turkish coast to the nearby Greek islands (e.g. Lesbos, Chios, Kos). In consequence of these developments, the number of sea arrivals in Italy fell in 2015 by 153,000, while in the Eastern Mediterranean there was a surge in migration pressure (mainly on Greece, with the number of sea arrivals increasing from 50,830 in 2014 to 885,386 in 2015). ${ }^{26}$ The largescale shift from the Central Mediterranean to the Aegean Sea reflects the fact that, in the period from January 1, 2014 until August 31, 2016, 62 percent of first-time asylum seekers in the EEA were from Asia (due to the departure from Turkey of hundreds of thousands of Syrians, Afghans and Iraqis), whereby an additional factor was Bulgaria's construction of a barrier along its land border with Turkey in 2014..$^{27}$ In view of the geographical location of their countries of origin, almost three-quarters of the migrants arrived in the EEA via the Balkans (or, indeed, originated from there).

In recent years, there has been a sharp increase in the number of illegal border crossings in western and southern areas of the Balkans, while the directions and trends of such migration have changed. In terms of granting refugee status and the prospect of asylum, the EU drew a sharp distinction - as early as 2015 - between migrants from the Western Balkans (e.g. Kosovo Albanians, Roma people) and refugees from the Middle East (e.g. Syrians). In consequence of this distinction, the number of asylum seekers from Serbia and Kosovo declined to an eighth of the previous figure between February and September 2015, while there was a sevenfold increase in the number of asylum seekers from Syria. Instead of taking the traditional route from Turkey to Central Europe (Istanbul-Sofia-Belgrade), the migrants from Asia entered Europe via the Greek islands and along the Athens-Thessaloniki-Skopje-

\footnotetext{
${ }^{26} \mathrm{http}$ ://frontex.europa.eu/trends-and-routes/easternmediterranean-route/

${ }^{27} \mathrm{http}$ ://bulgaria.bordermonitoring.eu/
}

Belgrade route (Figure 10). Until the closure of the Hungarian-Serbian border (September $15,2015)$, which was followed by the construction of the Hungarian border barrier, most migrants passing through the Balkans continued their journey to Western Europe (mainly to Germany) via Belgrade and Budapest (Figure 11).

Subsequently, (owing to the construction of Hungary's barrier along the HungarianCroatian border in October), a huge migration pressure fell on the Croatian-Serbian, Slovenian-Croatian and Austrian-Slovenian borders. In response, in November 2015, Austria and Slovenia (and Macedonia too) began to erect barriers on their southern borders. The aim of such barriers was to halt the ever-increasing number of illegal migrants. Owing in part to these actions but mostly to the EU-Turkey statement (March 20, 2016), since late March 2016, the number of migrants crossing by sea from Turkey to Greece has fallen to a mere fraction of the previous figure. ${ }^{28}$ In consequence, however, the migration pressure on Italy increased once more, leading to an equalisation of the annual number of registered illegal border crossings along the Central and Eastern Mediterranean routes (in the period until December 11, 2016). On both routes, the numbers were reduced to a minimum in the period from October until the end of the year. ${ }^{29}$

\section{Main destination countries of the recent international migration concerning the EEA}

From January 1, 2014 until August 31, 2016, 2.7 million asylum applications were registered in the EEA countries, which may significantly exceed the actual number of asylum seekers, because as a person travels through Europe, he or she may be registered as an

${ }^{28}$ https://data.unhcr.org/mediterranean/download. php?id=2244

${ }^{29}$ Eastern Mediterranean arrivals: 172,699, Central Mediterranean arrivals: 179,087 between January 1 and December 11, 2016. http://data.unhcr.org/ mediterranean/regional.php 


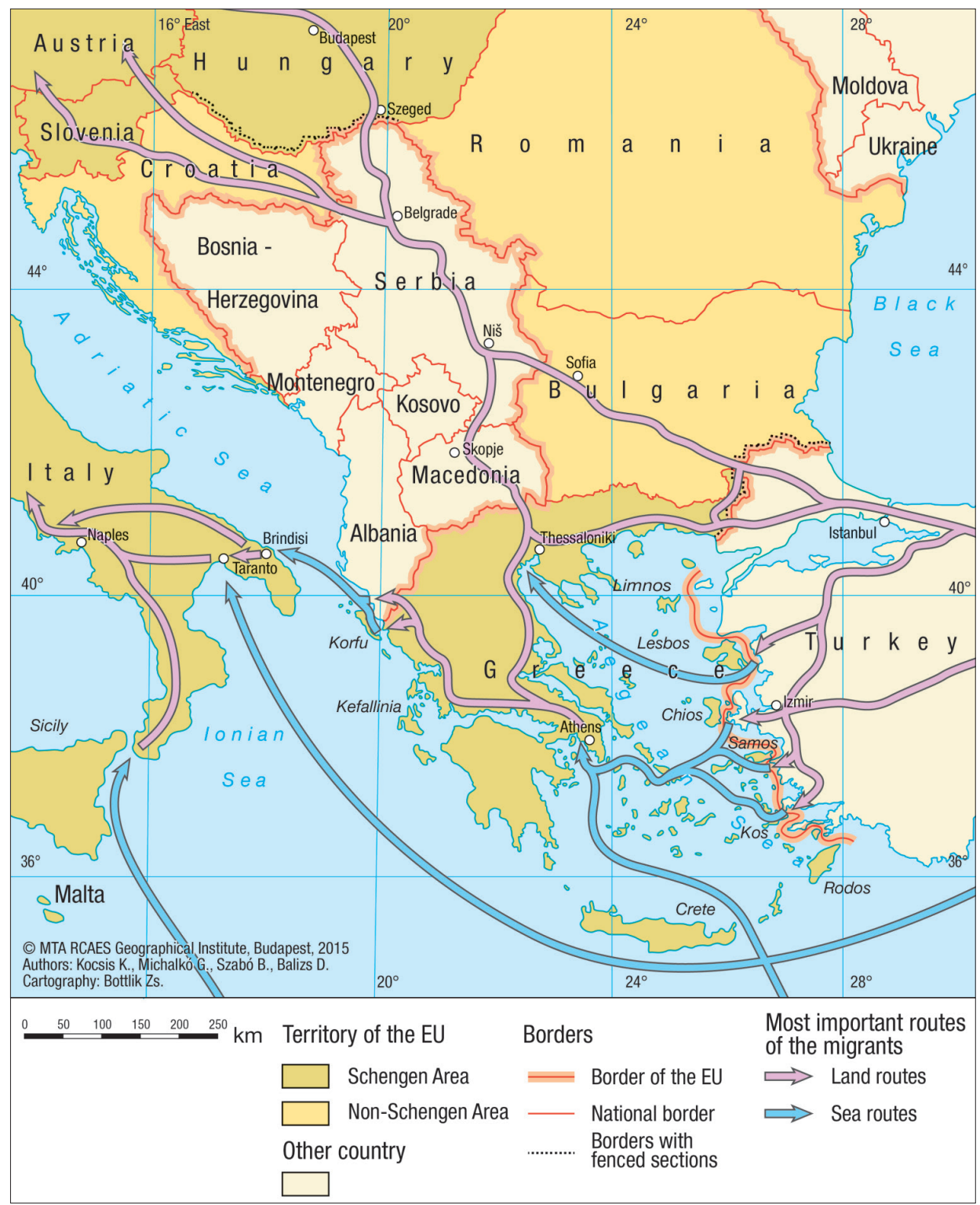

Fig. 10. Most important routes of the non-European migrants in Southeastern Europe (2014-2016). Source: see the map

asylum seeker in several different EU member states (e.g. in Greece, in Hungary and in Germany). This explains why the number of applications is high both in the destination countries (Germany, in particular) and in some transit countries where migrants' asylum applications were registered in line with the regulations (above all, in Hungary) (Figure 12).

The distribution of asylum applications shows significant geographical differences in terms of the sending countries, the entry routes of migrants, and their destinations. Almost 39 percent of asylum applications were lodged 


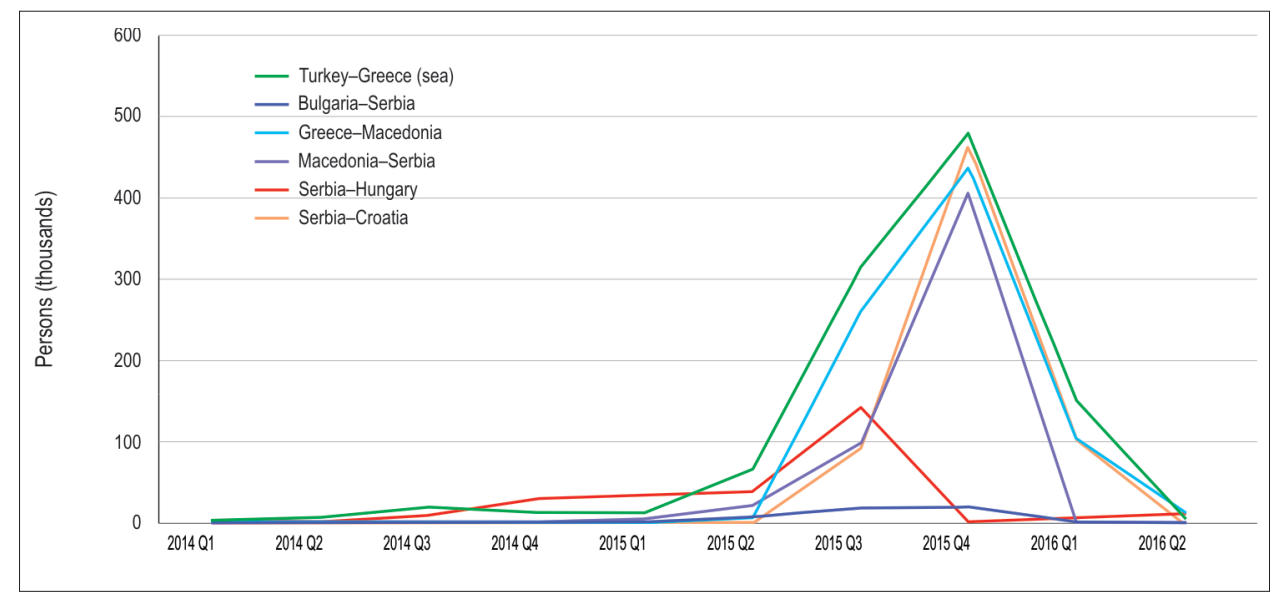

Fig. 11. Detected illegal border-crossings in selected border sections of Southeastern Europe (2014-2016). Source: http://frontex.europa.eu/publications/?c=risk-analysis

by people from SW Asia (mostly Syrians and Iraqis). The greatest numbers were recorded in Germany and Sweden (or, in transit, in Hungary and in Austria) (Figure 12). ${ }^{30}$

Out of almost 630,000 applications submitted by people from South Asia (mostly Afghans and Pakistanis), a third were registered by the German authorities, a sixth by the Hungarian authorities, and most of the rest by the Swedish, Austrian and Italian authorities. The highest numbers of North African Arab asylum seekers were seen in Germany and in France, and such applications formed the majority in Malta, which lies adjacent to Africa. Almost a half of arrivals from the western part of Sub-Saharan Africa were registered in Italy, while a significantly smaller proportion was registered in Germany or in France. The largest numbers of East African migrants (coming mainly from Eritrea or from Somalia, where a civil war is raging) sought asylum in Germany, Sweden and Switzerland. In the period until the spring/summer 2015, many asylum applications were lodged in the EEA (particularly in Germany and - in transit - in Hungary) by people from the Western Balkans (mainly from Kosovo and Albania). Most

\footnotetext{
${ }^{30}$ http://popstats.unhcr.org/en/asylum_seekers_ monthly
}

asylum requests made by Eastern Europeans (mainly Russians and Ukrainians) were registered in Germany, Poland and France.

According to UNHCR data, ${ }^{31}$ legally speaking, there were almost 3 million migrants residing in the EEA by the end of 2015, whereby only 49 percent had been granted official refugee status. The others were asylum seekers (asylum seeker: application rejected or under adjudication, $36.1 \%$ ) or stateless persons $(14.2 \%)$, or had some other legal status $(0.7 \%)$. The number and percentage of persons with refugee status is clearly the highest in those EEA countries with the highest living standards, which are the primary immigration destinations for migrants (Western and Northern Europe) (Figure 13). In these countries, migrants seeking a new home can rely on the networks that have been established by mostly Muslim immigrants over the years.

The number of persons with refugee status per 10,000 inhabitants is greater than 20 in these countries. The corresponding figure in countries of EEA with lower income that are less attractive to migrants - the former communist countries, and Spain and Portugal - ranges from 0 to 5 . A special category of migrants are stateless persons. These are peo-

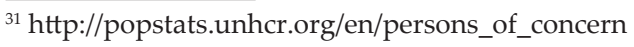




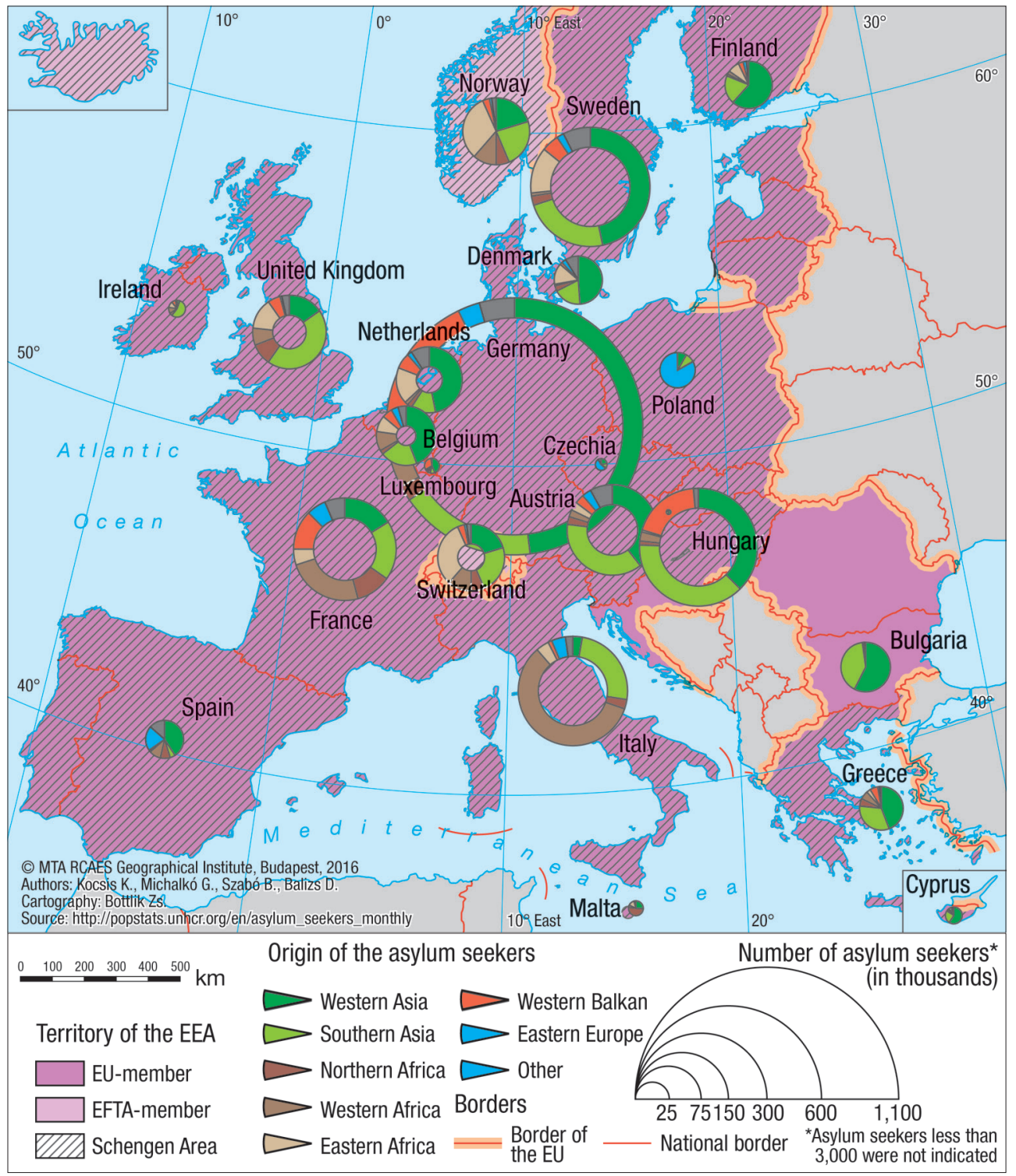

Fig. 12. Asylum seekers in the EEA by macroregion of origin (1 January, 2014 - 31 August, 2016). Source: see the map

ple who have an attachment to their place of residence, are not eligible for citizenship, and do not regard themselves as refugees. The numbers and percentages of such persons are particularly high in the Baltic countries (principally in Latvia and Estonia). The explanation for this phenomenon in the post-
Soviet republics is the presence of a large community of Russians (as well as smaller numbers of Belarusians and Ukrainians) who settled there between 1945 and 1989. Because they have not yet learned the official state language, these people have not acquired Estonian, Latvian or Lithuanian citizenship. 


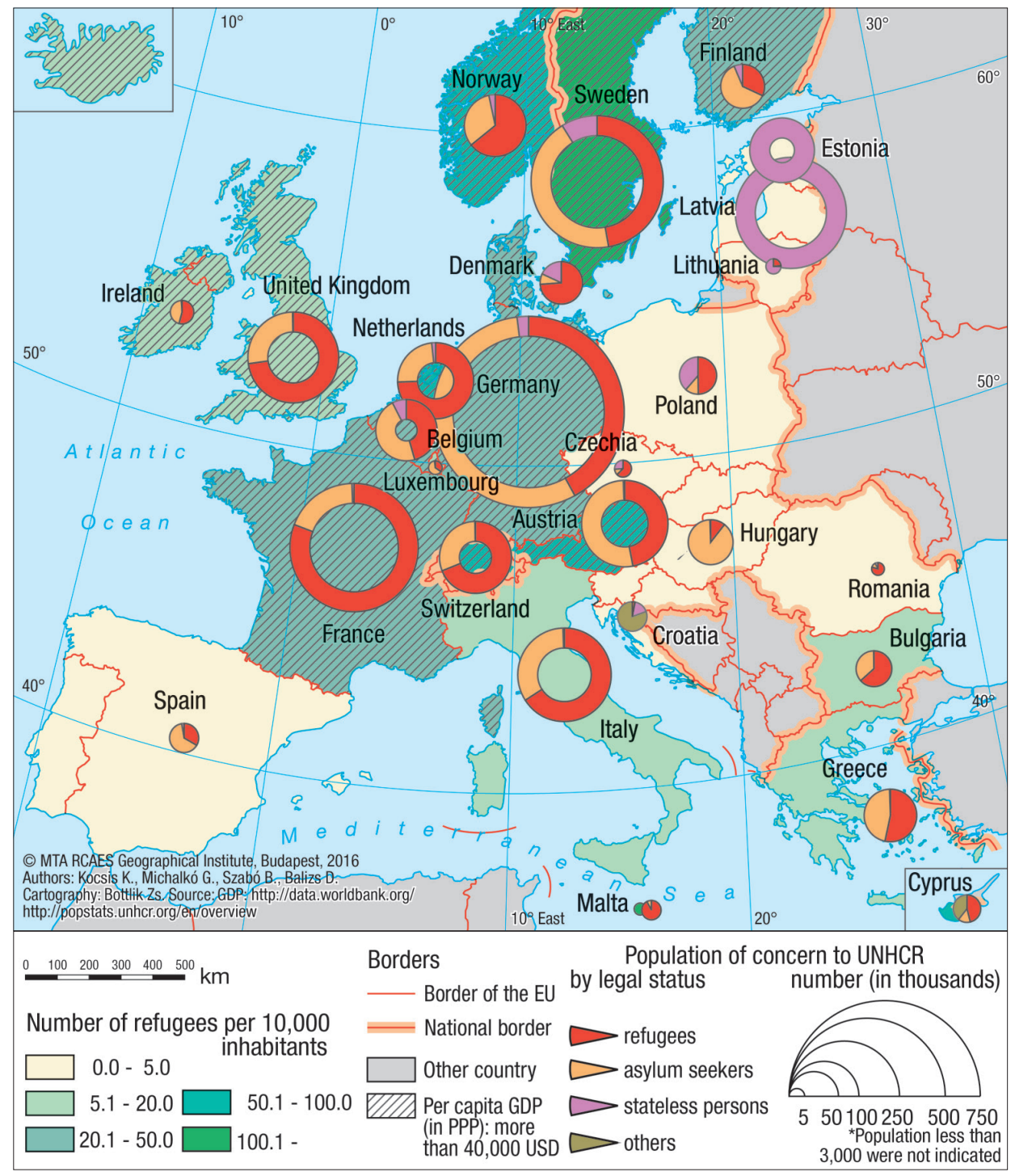

Fig. 13. Population of concern to UNHCR in the EEA by legal status (End of 2015). Source: see the map

During the recent European migrant crisis, the countries most affected by international migration targeting the EEA have been those situated in the most developed western and northern areas of Europe, which are particularly attractive to migrants, and those situated in the southern and south-eastern peripheral areas (e.g. Italy, Hungary, and the
Western Balkans), which have been particularly affected by temporary/transit migration.

\section{Conclusion}

As far as intercontinental migration is concerned, Europe was characterised by emigra- 
tion between the $16^{\text {th }}$ and mid-20 $0^{\text {th }}$ centuries (partly as a consequence of colonisation) and mainly by immigration thereafter. In consequence of post-WWII reconstruction, dynamic economic development, local labour shortages, and the decolonisation process, Western Europe received many migrants, initially from the Mediterranean region and subsequently (i.e. after the collapse of communism in 1989/90) from the post-communist European countries. Meanwhile, the core areas of the EEA became the main destination for migrants coming from predominantly Muslim regions in Asia and Africa.

This important process has recently accelerated and now constitutes mass migration. The global and regional causes of such intercontinental migration in the sending areas are as follows: the population boom, economic backwardness, unemployment, growing poverty, climate change, desertification, global political rivalries and local power changes, growing political instability, wartime destruction, multiple and cumulative crises, general hopelessness and despair. Partly in consequence of the events of the "Arab Spring" of 2011, in 2015 a wave of mass migration - mostly illegal immigration, with vast numbers of asylum seekers - reached Europe from adjacent regions in Asia and Africa.

The main features distinguishing this European migration crisis from earlier crises were: the arrival of an unprecedented number of migrants/refugees in the EU (the highest number since World War II); the migrants arrived predominantly by sea and from very great distances; the earlier crises were more geographically concentrated in terms of both the countries of origin and the countries of destination; the motives for migration and the national (ethnic) composition of the migrants are far more complex and diverse now than they used to be; today's migrants target - in a far more conscious fashion than did their predecessors - the Western European countries with their stronger economies and higher living standards; several European countries at the forefront of events were subjected relatively rapidly and unexpect- edly to substantial migration pressures (e.g. Italy, Greece, Hungary, Croatia). The rapid construction of European border barriers and the signing of migration agreements with Europe's neighbours (with Libya in earlier years, and more recently with Turkey) have very effectively influenced the direction and intensity of migration.

The global and regional causes of AfroAsian migration into Europe and the associated cumulative and multifaceted crises will not be resolved even in the medium term. Nor will the reasons for international migration cease to exist.

\section{REFERENCES}

BADE, K.J. 2003. Migration in European History. London, Blackwell Publishing.

BoттLIK, Z. 2009. Geographical and historical aspects of the situation of Muslim population in the Balkans. Hungarian Geographical Bulletin 58. (4): 257-280.

Bruk, S.I. and Apenchenko, V.S. ed. 1964. Atlas Narodov Mira. Glavnoe Upravlenie Geodezii i Kartografii. Moskva, Institut Etnografii im. N.N. MikluhoMaklaya.

Castles, S. and Miller. J.M. 2009. The Age of Migration. $4^{\text {th }}$ edition. New York, The Guilford Press.

Fassmann, H. and MüNZ, R. 1994. European Migration in the Late Twentieth Century. Historical Patterns, Actual Trends, and Social Implications. Laxenburg, Edward Elgar IIASA Austria.

Fischer, P.A., Martin, R. and StraubhaAr, T. 1997. Should I stay or should I go. In International Migration, Immobility and Development: Multidisciplinary Perspective. Eds.: Hammer, T., Brockman, G., Tamas, K. and FAist, T., Oxford, Berg, 49-90.

Gilbert, M. 2010. The Routledge Atlas of Jewish History. $8^{\text {th }}$ edition. London-New York, Routledge.

GLEICK, P.H. 2014. Water, Drought, Climate Change, and Conflict in Syria. Weather, Climate, and Society 6. 331-340.

INDA, J.X. and RosALDo, R. 2002. Introduction: A World in Motion. In The Anthropology of Globalization: A Reader. Eds.: Inda, J.X. and Rosaldo, R., Oxford, Blackwell Publishers, 3-46.

Jones, H.R. 1990. Population Geography. London, Paul Chapman Publishing Ltd.

Jürgenson, A. 2011. Ladina rahva seas. Argentina ja sealsed eestlased. Tallinn, Argo.

Káčerová, M., OndačKová, N. and MládeK, J. 2014. Time-space differences of population ageing in Europe. Hungarian Geographical Bulletin 63. (2): 177-199. 
Karácsonyi, D., Kocsis, K., Kovály, K. and Póti, J. 2014. East-West dichotomy and political conflict in Ukraine - Was Huntington right? Hungarian Geographical Bulletin 63. (2): 99-134.

Kelley, C.P., Mohtadi, Sh., Cane, M.A., Seager, R. and Kushnir, Y. 2015. Climate change in the Fertile Crescent and implications of the recent Syrian drought. Proceedings of the National Academy of Sciences (PNAS) 112. (11): 3241-3246.

KING, R. 2011. Geography and Migration Studies: Retrospect and Prospect. Population, Space and Place 18. 134-153.

KInG, R. and ÖвеRG, S. 1993. Introduction: Europe and the future of mass migration. In Mass Migration in Europe. The Legacy and the Future. Ed.: KING, R., London, Belhaven Press, 3-34.

King, R., Collyer, M., Fielding, A. and Skeldon, R. 2010. People on the Move. An Atlas of Migration. Berkeley, University of California Press.

Kocsis, K. 2001. Az albán kérdés etnikai és politikai földrajzi háttere (The ethnic and political geographical background of the Albanian questions). Földrajzi Értesítö / Hungarian Geographical Bulletin 50. (1-4): 161-190.

Kulischer, E.M. 1948. Europe on the Move. War and Population Changes, 1917-47, New York, Columbia University Press.

Lados, G. and Hegedús, G. 2016. Returning home: An evaluation of Hungarian return migration by different aspects. Hungarian Geographical Bulletin 65. (4): 321-330.

Lewis, W.A. 1978. The Evolution of the International Economic Order. Princeton, NJ, Princeton University Press.

Massey, D., Arango, J., Hugo, G., Kouaouci, A., Pellegrino, A. and Taylor, J.E. 1993. Theories of International Migration: A Review and Appraisal. Population and Development Review 19. (3): 431-466.

Newbold, K.B. 2014. Population Geography. Tools and Issues. London, Rowman \& Littlefield.
Ohligher, R., Schönwalder, K. and Triadafilopoulos, T. eds. 2003. European Encounters. Migrants, migration and European societies since 1945. Aldershot, Ashgate Publishing.

PeACH, C. 1968. West Indian Migration to Britain: A Social Geography. London, Oxford University Press.

Portes, A. and Zhou, M. 1993. The New Second Generation: Segmented Assimilation and Its Variants. Annals of the American Academy of Political and Social Science 530. Interminority Affairs in the U. S.: Pluralism at the Crossroads, 74-96.

Richmond, A.H. 1988. Sociological Theories of International Migration: The Case of Refugees. Current Sociology 36. (2): 7-25.

Robertson, R.L. 1996. The Ethnic Composition of Migration in the Former Soviet Union. Post-Soviet Geography and Econmics 37. (2): 113-128.

Robinson, V. 1996. Introduction: The Geographical Contribution to the Study of Human Migration. In Geography and Migration. Ed.: Robinson, V., Cheltenham, Elgar, 5-17.

Siegmund, A. and Frankenberg, P. eds. 2013. Klimakunde - Wetter, Klima aund Athmosphäre. Braunschweig, Diercke Spezial.

Sкор, E.H. 2001. Race and Place in the Adaptation of Mariel Exiles. International Migration Review 35. (2): 449-471.

Van Hear, N. 2010. Migration and diasporas. In Diasporas: concepts, identities, intersections. Eds.: KnotT, K. and McLoughlin, S., London, Zed Books, 34-38.

Woltman, K. and Newbold, K.B. 2009. Of Flights and Flotillas: Assimilation and Race in the Cuban Diaspora. The Professional Geographer 61. (1): 70-86.

ZelinsKy, W. and Lee, B.A. 1998. Heterolocalism: an alternative model of the sociospatial behaviour of immigrant ethnic communities. International Journal of Population Geography 4. 4-28. 